\title{
IMPLEMENTASI PEMBIAYAAN SALAM DENGAN PENDEKATAN HYBIRD CONTRACT
}

Oleh:

\author{
Wiwik Fitria Ningsih ${ }^{1}$ \\ Yuniorita Indah Handayani ${ }^{2}$
}

STIE Mandala Jember

Email:

wiwik@stie-mandala.ac.id

\begin{abstract}
ABSTRAK
Tujuan dari penelitian ini adalah untuk menganalisis implementasi pembiayaan salam dengan pendekatan hybird contract untuk mendukung bisnis pertanian.Jenis penelitian ini adalah konstruktif kualitatif. Analisa data yang digunakan mengikuti konsep yang diberikan Miles dan Huberman. Hasil penelitian ini menunjukkan bahwa pembiayaan salam bil wakalah adalah salah satu konsep inovasi dari produk pembiayaan salam, secara global inovasi pembiayaan salam ini sesuai dengan prinsipprinsip Islam. Di dalam prinsip-prinsip Islam melarang adanya bunga, spekulasi yang disengaja, ketidakjelasan dan manipulatif dalam transaksi. Pembiayaan salam bil wakalah ini masih perlu dibedah secara rinci tentang skema dan langkah-langkah sebelum atau setelah perjanjian kontrak, jadi jika berbeda dengan standar kontrak pembiayaan salam yang diatur dalam fatwa DSN-MUI, maka harus dibedah secara detail, apakah ada unsur riba, gharar, dan maysir.
\end{abstract}

Kata Kunci: akuntansi salam, hybrid contract, pembiayaan salam

\section{A. PENDAHULUAN}

Pertumbuhan perbankan syariah di Indonesia cukup baik, berdasarkan statistik perbankan syariah yang diterbitkan oleh Otoritas Jasa Keuangan (selanjutnya disebut OJK), pada tahun 2000 bank syariah memiliki 2 Bank Umum Islam (selanjutnya disebut sebagai BUS) termasuk Bank Muamalat Indonesia atau BMI dan Bank Syariah Mandiri atau BSM. Perbankan syariah mengalami pertumbuhan yang cepat di mana pada tahun 2019 data menunjukkan bahwa bank syariah telah memiliki 
12 BUS, termasuk BMI, BSM, BSMI, BRI Syariah, Bank Bukopin Syariah, Bank Victoria Syariah, BPD Jawa barat Banten Syariah, Panin Syariah Bank, PT. BCA Syariah, PT. BTPN Syariah dan PT. Maybank Syariah Indonesia dan 22 UUS (Unit Bisnis Syariah) dan 162 BPRS (Bank Pembiayaan Masyarakat Syariah).

Pesatnya pertumbuhan perbankan syariah juga disertai dengan pengembangan jenis produk dan variasi dalam kontrak sesuai dengan prinsip syariah. Namun ada masalah signifikan yang dihadapi perbankan syariah, yaitu komposisi produk pembiayaan yang masih didominasi oleh murabahah. Terdapat perbedaan yang signifikan antara komposisi pembiayaan yang diberikan oleh Bank Umum Syariah dan Unit Bisnis Syariah dengan kontrak murabahah sebagai kontrak jual beli dengan komposisi tertinggi dan menganggap kontrak sebagai kontrak jual beli dengan komposisi terendah yaitu nol rupiah. Keberadaan perjanjian diakui karena dalam data statistik perbankan syariah selalu terungkap dalam setiap laporannya. Namun, sangat disayangkan bahwa kontrak salam tidak berlaku untuk perbankan syariah. Sejak 2002 hingga saat ini, pembiayaan salam di Bank Umum Syariah dan Unit Bisnis Syariah tidak tersedia sama sekali (Ningsih \& Wardayati, 2016)

Pembiayaan salam secara hukum adalah halal, manfaat lain yang bisa didapatkan oleh pembeli adalah dalam bentuk agunan untuk mendapatkan barang yang dibutuhkan pada waktu yang diinginkan. Selain itu, pembeli akan mendapatkan harga yang cenderung lebih baik daripada pembelian saat ia membutuhkan barang. Manfaat lain juga akan diperoleh oleh penjual, termasuk penjual mendapatkan modal untuk menjalankan bisnisnya dengan cara halal sehingga penjual dapat menjalankan dan mengembangkan usahanya tanpa harus membayar riba.

Untuk mengatasi masalah pembiayaan dengan kontrak salam, upaya yang komprehensif dapat dibuat mengenai inovasi yang terkait dengan pembiayaan salam termasuk: 1. Pembiayaan salam bilakwakalah ; 2. Pembiayaan salam bil mudabahabah. Kedua inovasi pembiayaan salam ini berfokus pada perawatan aset salam setelahakhir perjanjian salam. Dimana dalam pembiayaan salam ini bank sebagai pembeli dantidakberniat untuk membuat aset salam sebagai persediaan, bank memerlukan strategi untuk menjual kembali aset salam (Ningsih \& Wardayati, 2016). Studi ini menganalisis implementasi pembiayaan salam dengan pendekatan hybird contract untuk mendukung bisnis pertanian.

\section{B. KAJIAN PUSTAKA}

\section{Definisi Kontrak Salam}

Penjelasan Pasal 3 ("Peraturan Bank Indonesia Nomor 9/19/PBI/2007," n.d.) tentang penerapan prinsip bank syariah dalam kegiatan penggalangan dana dan penyaluran dana dan layanan bagi bank syariah menyebutkan definisi salam s yaitu salam adalah transaksi jual beli barang dengan cara pemesanan dengan ketentuan tertentu dan pembayaran tunai di muka dibayar penuh. 


\section{Rukun dan ketentuan Bai 'As-Salam}

Syarat Bai 'as-salam harus memenuhi sejumlah pilar dan ketentuan syariah (Wasilah, 2014). Inilah pilar bersama dengan kondisi yang harus dipenuhi di setiap pilar yaitu: pelaku; Objek kontrak; Persetujuan diberikan/sighat. Pernyataan dan ekspresi sighat adalah salam satu sama lain dengan senang hati atau dengan sukarela antara pihak-pihak kontrak pelaku yang melakukan korespondensi lisan atau tertulis atau menggunakan sarana komunikasi modern.

\section{Jenis Kontrak Salam}

Ada dua jenis kontrak, yaitu salam salam dan salam paralel. Berikut adalah skema dan penjelasan dari dua jenis kontrak.

\section{Salam}

Setelah pembeli dan penjual setuju untuk membeli dan menjual pesanan barang dengan kondisi yang telah ditetapkan sebelumnya dengan menggunakan kontrak salam, maka pembeli mentransfer jumlah uang tunai penuh dari harga jual yang telah disepakati. Setelah barang pesanan diproses dan selesai maka penjual mengirimkan barang ke pembeli di mana lokasi pengiriman se menjaga dengan perjanjian di awal. Menurut DSN No. 05 / DSN-MUI / IV / 2000 pembatalan salam kontrak pada dasarnya diperbolehkan, selama tidak merugikan kedua belah pihak. Jika ada perselisihan antara dua pihak, maka masalahnya diselesaikan melalui Dewan Arbitrase Syariah setelah tidak ada kesepakatan dicapai dengan konsensus.

\section{Salam Paralel}

Prosedur paralel salam upacara pada upacara salam, tetapi perbedaannya melibatkan pihak ketiga (Wasilah, 2014). Salam paralel berarti melaksanakan dua transaksi bai 'as-salam antara bank dan pelanggan, dan antara bank dan pemasok atau pihak ketiga lainnya secara bersamaan. Ini terjadi karena penjual tidak memiliki barang yang dipesan dan memerintahkan orang lain untuk menyediakan barang yang dipesan (Antonio, 2015). Salam Paralel adalah salam yang berjalan secara bersamaan. Misalnya transaksi pertama antara pembeli dan bank syariah (sebagai penjual), dan transaksi kedua antara bank syariah (sebagai pembeli) dengan produsen sebagai penjual (Antonio, 2015). Salam paralel, implementasinya dalam perbankan dapat digambarkan sebagai berikut: 1) Pelanggan membutuhkan barang yang akan diproduksi terlebih dahulu; 2) Pelanggan menghubungi bank; 3) Bank berjanji untuk membayar pemesanan barang; 4) Bank memesan barang sesuai permintaan pelanggan pabrik; 5) Harga jual barang disepakati di awal, dan tidak berubah sampai barang jadi dibuat; 6) Waktu pembuatan perjanjian antara bank, produsen dan pelanggan; 7) Pelanggan berjanji untuk membeli barang setelah selesai; 8) Pelanggan dapat membayar sebagian besar harga jual barang pada awal kontrak dan membayar sisa harga jual sebelum barang diterima; 9) Setelah barang jadi dikirim ke pelanggan. 
Beberapa penelitian sebelumnya berkaitan dengan pembiayaan salam . (Ashari \& Saptana, 2005) meneliti masalah utama dalam pengembangan sektor pertanian yang disebabkan oleh modal yang lemah.Pemerintah telah berusaha mengatasi masalah ini dengan meluncurkan beberapa program untuk sektor pertanian. Program kredit berdasarkan sistem bunga menciptakan masalah baru seperti pembengkakan hutang petani dan kredit macet. Ashari dan Saptana menawarkan ulasan tentang solusi pembiayaan alternatif yang sesuai dengan prinsip syariah, salah satunya adalah perjanjian salam. Hasil penelitian inimenunjukkan bahwa keuangan syariah cukup prospektif untuk memperkuat modal di sektor pertanian. Untuk mendukung implementasinya di sektor pertanian, diperlukan penyelarasan para pembuat kebijakan dan sosialisasi intensif mengenai prinsip-prinsip keuangan Islam.

Dalam penelitian yang dilakukan oleh Affandi, (Affandi, 2013) membahas bagaimana makna pembiayaan salam didasarkan pada pemikiran perbankan syariah dan petani. Penelitian dilakukan dengan menggunakan metode etnometodologi dan dilakukan di daerah Probolinggo, Jawa Timur. Hasil penelitian menunjukkan bahwa pembiayaan salam dalam pandangan perbankan syariah adalah pembiayaan salam dengan logika uang, sedangkan menurut petani adalah pembiayaan salam dengan logika mekanisme alami. Ada perbedaan pemikiran antara perbankan Islam dan petani. Pertama, memahami pembiayaan kontrak salam. Kedua, risiko pembiayaan kontrak salam.

Ketiga, penggunaan pembiayaan kontrak salam. Keempat, catatan akuntansi untuk salam. Kelima, makna budaya dari pembiayaan kontrak salam. (Roziq, Hisamuddin, Wahyuni, \& Purnamawati, 2015) meninjau bagaimana implementasi dan masalah pembiayaan operasional salam untuk petani singkong, lembaga keuangan Islam (Bank Syariah, BPR Syariah dan Koperasi Syariah) dan usaha kecil yang terbuat dari singkong; faktor-faktor apa yang menghambat kegagalan dan pendorong keberhasilan sistem pembiayaan salam dan bagaimana model pembiayaan sistem salam sesuai dengan karakteristik petani singkong, lembaga keuangan syariah (Bank Syariah, BPR Syariah dan Koperasi Syariah) dan usaha kecil yang dibuat singkong. Hasil penelitian menemukan bahwa tidak ada dana untuksalam yang diperoleh petani singkong baik dari industri / tape bisnis, keripik singkong dan tepung singkong, di lembaga keuangan Islam seperti Bank Syariah Mandiri, Bank Muamalat, BPR Syariah ASRI Madani Nusantara dan BMT Sidogiri. Masalah yang dihadapi oleh petani singkong adalah kurangnya modal, kesulitan dalam pemasaran dan rendahnya kualitas singkong selama musim hujan, kegagalan panen, serangan hama, fluktuasi waktu dan harga, dan lamanya periode produksi dari penanaman hingga panen. Masalah yang akan dihadapi dalam pelaksanaan operasi sistem salam pembiayaan adalah bahwa tidak ada modal yang digunakan untuk membayar tunai dimuka, ada risiko penurunan modal, karakter buruk atau hasil yang dijual ke pihak lain karena kenaikan harga. Model pembiayaan salam untuk petani singkong, lembaga keuangan Islam (Bank Syariah, BPR Syariah dan Koperasi Syariah) dan usaha kecil yang terbuat dari singkong dapat dilakukan adalah pembiayaan paralel 
dengan model Islam tentang cara memodifikasi metode pembayaran seperti pembiayaan murabahah. Kurangnya pembiayaan untuk bank syariah di sektor pertanian adalah karena pengaruh risiko yang terkandung dalam bisnis pertanian. Studi ini menjelaskan bahwa untuk mengurangi risiko bisnis atau meningkatkan peluang keberhasilan dalam penerapan keuangan Islam di sektor pertanian, salah satu faktor utama adalah perlunya menciptakan model kemitraan bisnis terpadu antara pengusaha pertanian dan perbankan Islam. Bentuk kerja sama kemitraan dapat diwujudkan dalam pola hubungan inti plasma, subkontrak, perdagangan umum, atau kerja sama operasional agribisnis.

\section{METODE PENELITIAN}

Jenis penelitian ini adalah konstruktif kualitatif. Pendekatan kualitatif Konstruktive digunakan untuk membangun pernyataan berdasarkan perspektif pengetahuan (misalnya makna yang berasal dari pengalaman individu) (Creswell, 2003). Pendekatan konstruktif kualitatif digunakan untuk menjelaskan bagaimana menerapkan pembiayaan salam dengan pendekatan hybird contract untuk mendukung bisnis pertanian.Teknik analisis data yang digunakan dalam penelitian ini adalah mengikuti konsep yang diberikan Miles dan Huberman. Langkah-langkah yang dilakukan dalam proses analisis data sebagai berikut: 1) Pengumpulan data adalah data yang telah diperoleh melalui teknik wawancara dan dokumentasi yang dikumpulkan untuk membangun model yang kredibel, 2) Pengurangan data adalah proses pemilihan, dengan fokus pada penyederhanaan data yang masih mentah dari catatan yang diperoleh. Dengan cara meringkas data, akan diklasifikasikan, mengarahkan, dan membuang data yang tidak relevan akan disimpulkan. Jika masalah ditemukan bertambah maka akan melakukan pengkodean untuk setiap Keterangan yang diperoleh. 3) Penyajian data yaitu proses ketika data yang dibutuhkan telah siap untuk menggunakannya untuk mengatur presentasi. Bentuknya bisa berupa teks naratif, grafik, grafik atau matriks. 4) Upaya kesimpulan dilakukan terus menerus. Semakin banyak data diperoleh dan diproses, kesimpulan yang diperoleh akan lebih rinci dan kuat.

\section{HASIL DAN PEMBAHASAN}

Berdasarkan hasil penelitian (Ningsih \& Wardayati, 2016), untuk mengatasi permasalahan pembiayaan dengan akad salam dapat dilakukan upaya komperhensif dengan inovasi pembiayaan salam dengan pendekatan hybird contract diantaranya Pembiayaan salam bil wakalah dan Pembiayaan salam bil mudharabah

Kedua inovasi pembiayaan salam tersebut menitikberatkan pada perlakuan aset salam setelah berakhirnya akad salam. Dimana dalam pembiayaan salam ini bank 
sebagai pembeli dan tidak berniat menjadikan aset salam sebagai persediaan, maka bank memerlukan strategi untuk menjual kembali aset salam.

Untuk membangun model bisnis, (Osterwalder \& Yves, 2013) mengatakan ada sembilan basic building blocks yang harus diperhatikan. Sembilan unsur tersebut adalah key activities, key partnership, key resources, value propositions, customer relationship, channels, customer segment, cost structrure, dan revenue streams. Berikut uraian mengenai kedua inovasi pembiayaan salam tersebut

\section{Pembiayaan Salam Bil Wakala}

Pembiayaan salam bil wakalah adalah pembiayaan salam dimana penjualan kembali aset salam dengan menggunakan sistem wakalah. Dalam pembiayaan salam ini, nasabah yang menghubungi bank adalah nasabah dengan profesi sebagai petani/produsen. Sehingga dalam hal ini bank sebagai pembeli, jika pihak bank menyanggupi untuk membiayainya. Namun tujuan bank dalam membeli aset salam tersebut bukanlah untuk dijadikan sebagai persediaan, maka bank menjual kembali aset salam tersebut dengan sistem wakalah yaitu melimpahkan kekuasaan atas aset salam untuk dijual kembali, yang menerima kuasa dalam hal ini yaitu nasabah bai salam yang bersangkutan. Pembiayaan salam bil wakalah dalam pelaksanaanya berpedoman pada Fatwa DSN Nomor 05/DSN-MUI/IV/2000 tentang ketentuan jual beli salam dan Fatwa DSN Nomor 10/DSN-MUI/IV/2000 tentang wakalah. Berikut skema atas pembiayaan salam bil wakalah tersebut;

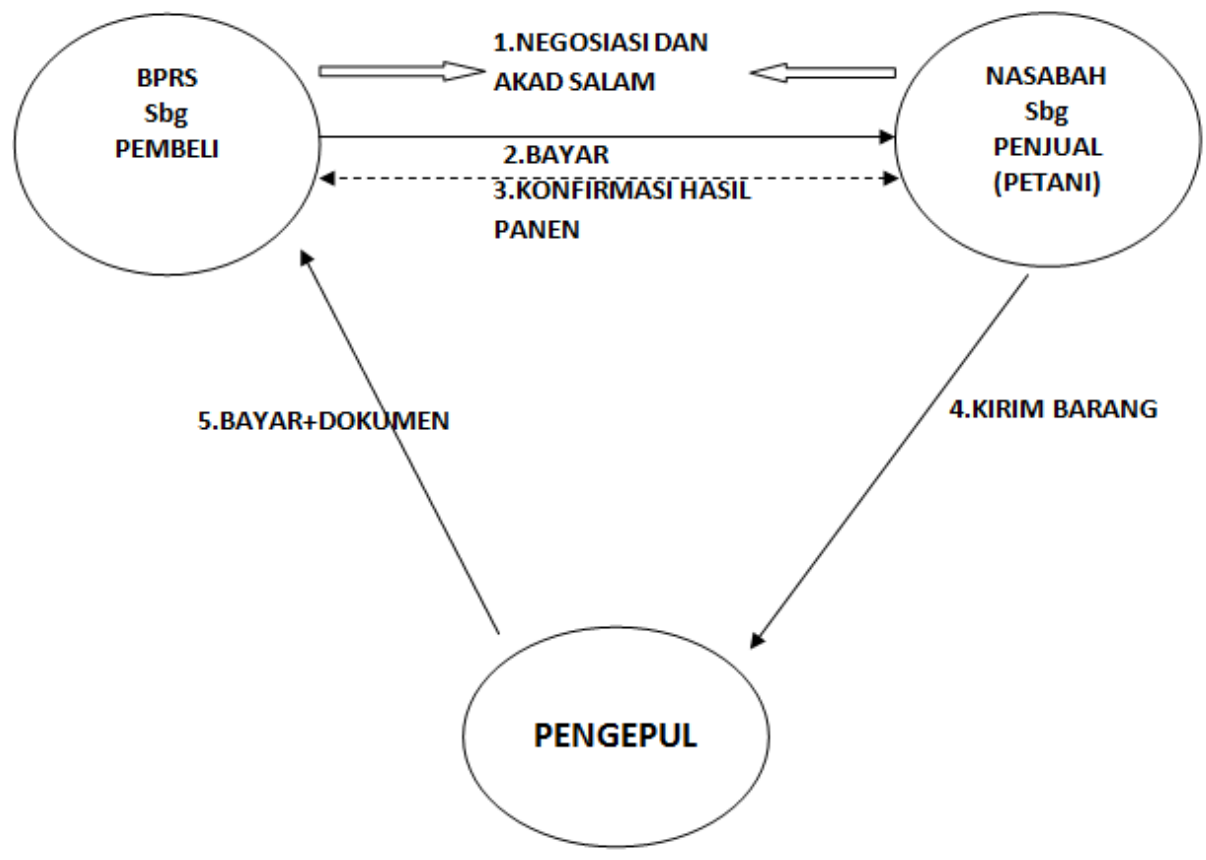

Gambar 1. Skema pembiayaan salam bil wakalah 
Keterangan:

Sumber: Ningsih (2016)

1) Pihak BPRS dan nasabah negosiasi dan menyepakati akad salam

2) BPRS membayar penuh kepada nasabah

3) Nasabah konfirmasi atas hasil panen

4) Nasabah mengirim hasil panen kepada pengepul

5) Pengepul membayar penuh kepada BPRS

Gambar 1 menunjukkan skema pembiayaan salam bil wakalah dimana skema pembiayaan salam bil wakalah pernah diterapkan oleh BPRS Bumi Rinjani Probolinggo. Namun pembiayaan salam bil wakalah yang dimaksud disini terdapat perbedaan dengan salam bil wakalah yang pernah diterapkan oleh BPRS Bumi Rinjani Probolinggo. Perbedaannya terletak pada saat proses penyerahan uang dan dokumen hasil penjualan aset salam milik BPRS. Jadi pembayaran atas aset salam dilakukan secara langsung antara pembeli/pengepul dengan pihak BPRS.

Berakhirnya akad salam pada saat nasabah bai 'al salam panen dan hasil panen sesuai dengan kesepakatan. Setelah panen nasabah bai 'al salam menghubungi pihak bank untuk dilakukan proses pelunasan sesuai dengan kesepakatan diawal. Jika barang sesuai dengan kesepakatan, maka hasil panen yang menjadi hak bank dititipkan kepada nasabah bai 'al salam yang bersangkutan untuk dijual kembali dengan menggunakan sistem wakalah. Disamping itu, pihak bank harus memiliki catatan yang jelas mengenai aset salam mengenai stock aset salam, hasil penjualan disertai dengan bukti nota penjualannya. Setelah aset salam tersebut berhasil dijual maka nasabah bai salam melakukan konfirmasi kepada pihak bank atas siapa pembeli yang telah membelinya. Uang hasil penjualan aset salam milik bank disertai dengan nota penjualan oleh pembeli diserahkan langsung kepada BPRS dimana waktu dan tempat sesuai dengan kesepakatan kedua belah pihak. Sehingga dengan cara seperti ini pihak bank tidak harus memiliki gudang atau tempat penyimpanan aset salam.

Hal terpenting yang harus diperhatikan dalam pembiayaan salam bil wakalah adalah titik akad harus terpisah, namun diperkuat dengan wa'd. Dimana wa'd ini sesuai dengan Fatwa DSN No.85/DSN-MUI/XII/2012 bahwa janji (wa'd) sering digunakan dalam transaksi keuangan dan bisnis yang bersifat tunggal, paralel dan/atau dalam transaksi yang multi akad (al-'uqud al-murakkabah). Sebagaimana yang telah disampaikan oleh Bapak Achmad Zaky selaku Chairman of Islamic Finance and Accounting Studies (IFAS), Universitas Brawijaya bahwa model pembiayaan salam bil wakalah rawan atau beresiko ta'alluq atau hielah (siasat agar seolah-olah sesuai syariah), dimana titik kerawanan tersebut adalah kapan akad salam bil wakalah ini berlangsung. Misalkan pada saat diawal akad atau bersamaan dengan akad salam dilangsungkan, maka disinilah letak problemnya. Sehingga akad tersebut perlu dipisah, dimana diperlukan solusi tambahan berupa wa'ad. Meskipun Bapak Achmad Zaky memiliki catatan pribadi bahwa munculnya Fatwa DSN No.85 tersebut beresiko terjadi berbagai "kekacauan" syar'i dan kerawanan ta'alluq, namun dalam hal ini terkait masalah fiqh dan ijtihad, maka asumsi dari Bapak Achmad Zaky adalah 
bahwa DSN sudah memfatwakan maka bisa dikatakan Mubah/halal. Maka hal ini memperkuat konsep pembiayaan salam bil wakalah dimana titik akad harus terpisah namun diperkuat dengan $w a ' d$.

Di sisi lain, untuk membangun model inovasi pembiayaan salam bil wakalah harus memenuhi sembilan basic building blocks sebagai acuan membuat rencana bisnis.sembilan basic building block harus diperhatikan dalam membangun model bisnis (Osterwalder dan Pigneur, 2013). Berikut ini uraian mengenai sembilan basic building blocks untuk pembiayaan salam, penjualan kembali aset salam dengan sistem wakalah:

1) Key activities, karena nasabah yang mengajukan pembiayaan salam adalah petani, maka bank sebagai pembeli jika menyanggupi pembiayaan salam tersebut. Bank membuat kontrak dengan petani untuk membeli hasil pertaniannya dengan kualitas, kuantitas dan harga yang telah disepakati diabil. Setelah itu, bank menjual kembali hasil pertanian tersebut dengan menggunakan sistem wakalah. Dimana pihak yang menerima kuasa tersebut adalah nasabah bai salam yang bersangkutan.

2) Key partnership, agar pembiayaan salam ini berjalan optimal, maka bank disarankan untuk mempunyai patner. Patner dalam pembiayaan ini adalah petani dan atau perusahaan yang menggunakan hasil pertanian.

3) Key resources, sumber daya yang dibutuhkan adalah financial resources. Dalam pembiayaan salam, bank harus membayar secara penuh diabil atas aset salam yang dipesan.

4) Value propositions, dalam produk pembiayaan dengan akad salam memiliki value propotitions yang unik dimana masa pembiayaan yang cukup singkat yaitu dua sampai dengan enam bulan. Sehingga nasabah yang menggunakan produk ini dapat meningkatkan kualitas hasil pertaniannya karena dapat memenuhi inpur barang yang dibutuhkan untuk menjaga kualitas hasil panen. Contohnya yaitu untuk pembelian pupuk.

5) Clients relationship, salah satu strategi pemasaran untuk meningkatkan keuntungan, pendapatan, memperoleh nasabah baru serta mempertahankan loyalitas nasabah adalah dengan membangun hubungan baik dengan para nasabah yang dimiliki. Dalam hal ini bank dapat mengimplementasikan call center dan atau personal assistance yaitu berinteraks langsung dengan nasabah maupun calon nasabah. Jadi pihak bank dapat menawarkan secara langsung pembiayaan salam mengenai langkah-langkah dalam pembiayaan tersebut, kelebihan beserta keuntungannya.

6) Channels, untuk memperoleh partner network yang memiliki kredibilitas yang baik misalkan melalui forum atau komunitas profesional. 
7) Clients segment, dalam hal produk pembiayaan ini secara khusus adalah petani, namun produsen barang industri juga dapat menggunakan produk pembiayan salam.

8) Cost structrure, yaitu jenis dan besarnya biaya yang harus dibayar oleh perusahaan dalam rangka memproduksi dan menjual barang atau jasa. Dalam penyaluran pembiayaan salam, biaya yang timbul adalah biaya pembelian hasil pertanian yang dilakukan secara penuh dimuka. Sedangkan untuk penjualan kembali aset salam tersebut, bank menggunakan sistem wakalah sehingga bank dapat terhindar dari biaya-biaya, misalkan biaya tenaga kerja, biaya transportasi untuk mengangkut barang, biaya pemeliharaan, dan lain-lain.

9) Revenue flows, untuk produk pembiayaan salam, bank akan mendapatkan aliran pendapatan dari hasil penjualan aset salam.

Keuntungan menggunakan pembiayaan salam bil wakalah adalah Pihak bank tidak harus memiliki gudang atau tempat penyimpanan aset salam, dengan demikian pihak bank dapat terhindar dari biaya-biaya, misalkan biaya tenaga kerja, biaya transportasi untuk mengangkut barang, biaya pemeliharaan, dan lain-lain. Sedangkan kelemahannya adalah default atau kelalaian, nasabah lalai dalam menjaga aset salam yang dititipkan oleh pihak bank, sehingga dapat menyebabkan nilai aset salam tersebut turun; side streaming yaitu nasabah bai salam menggunakan modal salam tidak seperti yang disebutkan dalam kontak.

\section{Pembiayaan Salam bil mudharabah}

Pembiayaan salam bil mudharabah adalah sistem pembiayaan salam, dimana hasil dari proses pembiayaan salam yaitu aset salam diserahkan kepada agen penjual yang telah ditunjuk oleh bank, dimana akad yang digunakan antara agen dan bank menggunakan akad mudharabah. Jadi sebelum adanya transaksi pembiayaan salam, pihak bank telah melakukan kerjasama dengan agen penjualan dengan menggunakan akad Mudharabah. Dengan menggunakan akad mudharabah artinya pemilik dana dalam hal ini adalah bank melakukan akad kerjasama dengan agen untuk melakukan kegiatan usaha, laba dibagi atasdasar nisbah bagi hasil menurut kesepakatan kedua belah pihak, sedangkan bila terjadi kerugian akan ditanggung oleh pemilik dana kecuali disebabkan oleh misconduct, negligence, atau violation oleh pengelola dana. Pembiayaan salam bil mudharabah merupakan dua akad yang terpisah. Dimana pembiayaan salam bil mudharabah yang dimaksud dalam konsep ini dilaksanakan sesuai dengan Fatwa DSN Nomor 05/DSN-MUI/IV/2000 yang berisi tentang ketentuan jual beli salam dan Fatwa DSN Nomor 07/DSN-MUI/IV/2000 tentang pembiayaan mudharabah (qiradh).

Secara sederhana, pembiayaan salam bil mudharabah dapat digambarkan dengan skema berikut: 


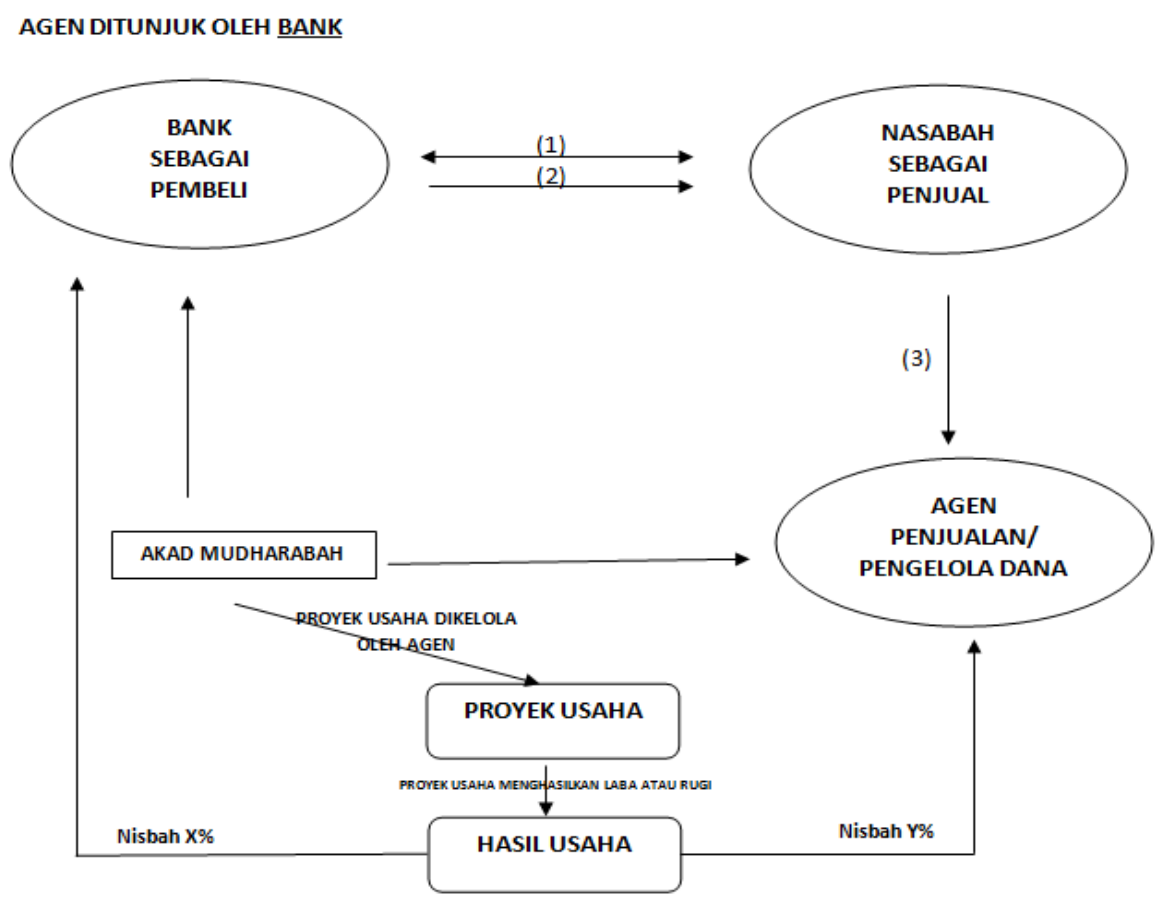

\section{Gambar 2. \\ Skema Pembiayaan Salam bil mudharabah \\ Sumber: Peneliti, data diolah (2016)}

\section{Keterangan:}

1) Pihak bank dan nasabah menyepakati akad salam

2) Bank membayar penuh kepada nasabah

3) Nasabah menyerahkan hasil produksinya kepada agen yang telah ditunjuk oleh bank

Pada Gambar 2 menunjukkan skema dari pembiayaan salam bil mudharabah dimana bank melakukan akad mudharabah dengan pengelola aset salam yang bertindak sebagai agen penjualan. Agen penjualan bertindak sebagai pengepul, yaitu menjual kembali aset salam kepada pedagang atau konsumen secara langsung. Apabila proyek usaha menghasilkan keuntungan maka keuntungan tersebut dibagi sesuai dengan nisbah yang telah ditentukan sebelumnya, misalkan bank dan agen dengan perbandingan 60:40. Apabila mengalami kerugian maka kerugian tersebut ditanggung sepenuhnya oleh pemilik dana (yakni bank). Selanjutnya apabila ada nasabah mengajukan pembiayaan salam, maka bank melakukan akad salam kepada nasabah, dan bank menyerahkan modal salam secara penuh di awal dengan ketentuan harga, kualitas, kuantitas barang yang jelas, dimana harga tersebut merupaka harga dibawah harga pasar (harga pengepul). Setelah nasabah bai salam akan melunasi 
pembiayaannya, jika barang sesuai dengan kesepakatan diawal, maka nasabah bai salam menyerahkan barang hasil produksinya tersebut kepada agen penjualan yang telah ditunjuk sebelumnya oleh bank.

Catatan penting mengenai produk pembiayaan salam bil mudharabah adalah pembiayaan salam bil mudharabah merupakan dua akad yang terpisah dan harus dipastikan terhindar dari ta'alluq. Seperti yang telah dituturkan oleh bapak Achmad Zaky bahwa jika pembiayaan salam bil mudharabah sebagai satu kesatuan akad (titik transaksinya bersamaan) maka tidak pas, kurang sesuai dengan ketentuan karakteristik transaksi syariah pada KDPPLKS terkait adanya gharar (ketidakpastian). Jadi dalam pembiayaan salam bil mudharabah, kedua akad harus terpisah dan harus dipastikan terhindar dari ta'alluq.

Disamping itu, untuk membangun model inovasi pembiayaan salam yang harus memenuhi sembilan basic building blocks, dimana sembilan basic building block harus diperhatikan dalam membangun model bisnis dalam mengarahkannya ke implementasi model bisnis yang superior (Osterwalder \& Yves, 2013). Berikut ini uraian mengenai sembilan basic building blocks untuk pembiayaan salam bil mudharabah:

1) Key activities, karena nasabah yang mengajukan pembiayaan salam adalah petani, maka bank sebagai pembeli jika menyanggupi pembiayaan salam tersebut. Bank membuat kontrak dengan petani untuk membeli hasil pertaniannya dengan kualitas, kuantitas dan harga yang telah disepakati diabil. Setelah itu, jika kualitas hasil petanian sesuai dngan kesepakatan, maka petani menyerahkan hasil pertanian yang menjadi hak bank kepada agen yang telah ditunjuk oleh bank.

2) Key partnership, agar pembiayaan salam bil mudharabah ini berjalan optimal, maka bank disarankan untuk mempunyai patner. Patner dalam pembiayaan ini adalah petani dan agen penjualan hasil pertanian.

3) Key resources, sumber daya yang dibutuhkan adalah financial resources. Dalam pembiayaan salam bil mudharabah, bank harus membayar secara penuh diabil atas aset salam yang dipesan. Setelah hasil pertanian yang menjdi aset salam piha bank, diserahkan kepada agen yang telah ditunjuk oleh bank untuk dijual kembali kepada pedagang.

4) Value propositions, dalam produk pembiayaan salam bil mudharabah memiliki value propotitions yang unik dimana masa pembiayaan yang cukup singkat yaitu dua sampai dengan enam bulan. Sehingga nasabah yang menggunakan produk ini dapat meningkatkan kualitas hasil pertaniannya karena dapat memenuhi input barang yang dibutuhkan untuk menjaga kualitas hasil panen. Contohnya yaitu untuk pembelian pupuk. Dan agen penjualan dapat memperoleh produk untuk dijual kembali. 
5) Clients relationship, salah satu strategi pemasaran produk pembiayaan salam bil mudharabah untuk meningkatkan keuntungan adalah dengan menggandeng patner yang memiliki kemampuan untuk menjual kembali hasil pertanian kepada pedagang maupun kepada konsumen secara langsung, misalkan membuat website untuk menjual hasil pertanian secara online. Sedangkan untuk memperoleh nasabah baru serta mempertahankan loyalitas nasabah adalah dengan membangun hubungan baik dengan para nasabah yang dimiliki. Dalam hal ini bank dapat mengimplementasikan call center dan atau personal assistance yaitu berinteraksi langsung dengan nasabah maupun calon nasabah. Jadi pihak bank dapat menawarkan secara langsung pembiayaan salam bil mudharabah mengenai langkah-langkah dalam pembiayaan tersebut, kelebihan beserta kelemahannya.

6) Channels, untuk memperoleh partner network yang memiliki kredibilitas yang baik misalkan melalui forum atau komunitas profesional.

7) Clients segment, dalam hal produk pembiayaan salam bil mudharabah adalah petani, namun produsen barang industri juga dapat menggunakan produk pembiayan salam bil mudharbah, mislakan prdusen garment.

8) Cost structrure, yaitu jenis dan besarnya biaya yang harus dibayar oleh bank dalam rangka menyalurkan produk pembiayaan salam bil mudharabah. Dalam penyaluran pembiayaan salam bil mudharabah, biaya yang timbul adalah biaya pembelian hasil pertanian yang dilakukan secara penuh dimuka. Sedangkan untuk penjualan kembali aset salam tersebut, bank telah menunju agen penjualan untuk menjual aste salam tersebut kepada pedagang maupun konsumen secara langsung.

9) Revenue flows, untuk produk pembiayaan salam bil mudharabah, bank akan mendapatkan aliran pendapatan dari hasil penjualan aset salam yang dijual oleh agen penjualan yang telah ditunjuk oleh bank dengan nisbah yang telah ditentukan sebelumnya.

Keuntungan menggunakan jenis pembiayaan salam bil mudharabah adalah Pihak bank tidak harus memiliki gudang atau tempat penyimpanan aset salam, dengan demikian pihak bank dapat terhindar dari biaya-biaya, misalkan biaya tenaga kerja, biaya transportasi untuk mengangkut barang, biaya pemeliharaan, dan lain-lain; bank akan memperoleh peningkatan bagi hasil pada saat keuntungan usaha agen penjualan meningkat; Sedangkan kelemahannya adalah default atau kelalaian yang disengaja oleh agen maupun nasabah bai salam; side streaming yaitu nasabah bai salam menggunakan modal salam tidak seperti yang disebutkan dalam kontak; penyembunyian keuntungan oleh agen penjualan. 


\section{E. SIMPULAN}

Studi ini mengeksplorasi implementasi produk pembiayaan salam dengan pendekatan hybird contract. Pembiayaan salam bil wakalah adalah salah satu konsep inovasi dari produk pembiayaan salam. Menurut peneliti, secara global pembiayaan inovasi salam, pembiayaan salam bil wakalah; sesuai dengan prinsip-prinsip Islam. Di mana ada keindahan dalam prinsip-prinsip Islam yang melarang unsur komersial yang barangnya najis; bunga; perjudian dan spekulasi yang disengaja; ketidakjelasan dan manipulatif dalam transaksi tetapi masih perlu dibedah secara rinci tentang skema dan langkah-langkah sebelum atau setelah perjanjian kontrak, jadi jika berbeda salam standar kontrak diatur dalam fatwa DSN-MUI harus dibedah satu per satu, apakah ada unsur riba, gharar, dan maysir.

Penelitian ini belum membedah secara detail mengenai konsep pembiayaan salam bil wakalah dan pembiayaan salam bil mudharabah mengenai skema dan setiap langkah-langkahnya sebelum akad atau sesudah akad.

\section{DAFTAR PUSTAKA}

Affandi, A. (2013). MAKNA PEMBIAYAAN SALAM PERSPEKTIF PERBANKAN SYARIAH DAN PETANI DI PROBOLINGO. Jurnal Ilmiah Mahasiswa FEB, 2(2). Retrieved from https://jimfeb.ub.ac.id/index.php/jimfeb/article/view/1027

Antonio, M. S. (2015). Bank Syariah: Dari Teori ke Praktek. Jakarta, DKI Jakarta, Indonesia: Gema Insani Press.

Ashari, \& Saptana. (2005). Prospek Pembiayaan Syariah untuk Sektor Pertanian. Forum Penelitian Agro Ekonomi , 23 (2), 132-147.

Creswell, John W. (2003). Research Design Qualitative, Quantitative, And Mixed Methods Approaches. Sage Publications. pp.3-26

DSN-MUI. (2000). Fatwa DSN-MUI No. 05/DSN-MUI/IV/2000 tentang Jual Beli Salam.(online), (www.dsnmui.or.id)

DSN-MUI. (2000). Fatwa DSN-MUI No. 10/DSN-MUI/IV/2000 tentang Wakalah.(online), (www.dsnmui.or.id)

DSN-MUI. (2012). Fatwa DSN-MUI No. 85/DSN-MUI/XII/2012 tentang Janji (Wa'ad) Dalam Transaksi Keuangan Dan Bisnis Syariah.(online), (www.dsnmui.or.id)

Ningsih, W. F., \& Wardayati, S. M. (2016). Modification Finance of Salam and the 
Implications for Salam Accounting Treatment in Indonesia. Procedia-Social and Behavioral Sciences, 528-533. (Antonio, 2015)https://doi.org/10.1016/j.sbspro.2016.05.030

Osterwalder, A. P., \& Yves. (2013). Business Model Generation: A Handbook for Visionaries, Game Changers, and ... - Alexander Osterwalder, Yves Pigneur Google Buku. John Wiley \& Sons. Retrieved from https://books.google.co.id/books?hl=id\&lr=\&id=UzuTAwAAQBAJ\&oi=fnd\&p $\mathrm{g}=\mathrm{PA} 9 \& \mathrm{dq}=$ basic+building+blocks\%3B+osterwalder\&ots=yXJTAeCc$\mathrm{w} \&$ sig=ES3BkM7QobvmRDw59IbK92dJR0Y\&redir_esc=y\#v=onepage\&q=ba sic building blocks\%3B osterwalder\&f $=$ false

Peraturan Bank Indonesia Nomor 9/19/PBI/2007. (n.d.). Retrieved April 20, 2020, from https://www.ojk.go.id/id/kanal/perbankan/regulasi/peraturan-bankindonesia/Pages/peraturan-bank-indonesia-nomor-9-19-pbi-2007.aspx

Roziq, A., Hisamuddin, N., Wahyuni, N. I., \& Purnamawati, I. (2015). MODEL PEMBIAYAAN SALAM PADA PETANI SINGKONG DAN USAHA KECIL BERBAHAN SINGKONG DI KABUPATEN JEMBER. JURNAL AKUNTANSI UNIVERSITAS JEMBER, 12(2), 43. https://doi.org/10.19184/jauj.v12i2.1410

Wasilah, S. N. (2014). Akuntansi Syariah di Indonesia. Indonesia: Salemba Empat. Retrieved from http://kin.perpusnas.go.id/DisplayData.aspx?pId=39982\&pRegionCode=TRUN OJOYO\&pClientId=639; 